\title{
Tasks and Prospects of Master's Degree Program's Development in Oil and Gas Trading in Russian Federation
}

\author{
Larisa A. Mierin \\ National Economy Department \\ St. Petersburg State Economic Univer-sity of Economics \\ Saint-Petersburg, Russia \\ mierin.1@unecon.ru
}

\author{
Tatiana G. Tumarova \\ Institute of Master programs \\ St. Petersburg State Economic Univer-sity of Economics \\ Saint-Petersburg, Russia \\ tumarova.t@unecon.ru
}

\author{
Nina S. Slavetskaya \\ Institute of Master programs \\ St. Petersburg State Economic Univer-sity of Economics \\ Saint-Petersburg, Russia \\ nslavetskaya@mail.ru
}

\begin{abstract}
Recently, the professional community has showed interest in professional education in the area of oil and gas trading. The absence of such master's degree program in Russia offers the opportunity to launch master's program with economics and oil and gas specificity according to professional and federal state educational standards with aim to combine requests of employers and students
\end{abstract}

Keywords: master's degree programs, education, oil and gas trading, university, employer

\section{INTRODUCTION}

In 1992, the preparation of bachelors and masters act in the Russian Federation was actively introduced in universities in accordance with the decision of the academic council of the university. However, until 2010, master's degree for the Russian education system was not a mass phenomenon. In 2012, master programs as the second stage of higher education was enshrined in the Federal Law "On Education in the Russian Federation" [1]. Prior to this, master's programs were enshrined by individual universities (for example, Moscow State University), following the example and models of Western universities. Over the past 9 years of the implementation of three-level education - undergraduate, graduate, post-graduate studies, considerable experience has been accumulated, there are both successes and problems related, first of all, to the mentality of the labor market participants who did not immediately manage to perceive the new player - the master, and his differences from the previous one "specialist".

\section{REVIEW AND RESEARCH Methods}

The modern Russian educational system, like any other, is undergoing transformation period associated with several key challenges that are caused by increasing uncertainty in the economy, accelerating economic processes, changing basic technologies and professions. Different authors make different lists of such challenges $[2,3,4]$, but they all agree on the main thesis, that the solution is transition to a new stage of innovative development of the economy and society, defined as the knowledge economy. As a result, the role of universities, as development institutes and generators, actively introducing new forms and methods of teaching, and ensuring the implementation of the global trend - education through life [5], is multiplied.

The processes that universities face in modern developed economies are directly related to these challenges and include:

- difficulties of forecasting demand and needs for certain specialists in the future;

- need for flexible "adjustment" in the training of specialists to meet the new demands of changing labor markets;

- ensuring the continuity of education, ranging from school to postgraduate.

At the same time, the educational community, as well as the business community, should carefully consider the changes that are defined by general trends in the world and in Russia, which determine the main tasks and opportunities in 
- implementation of joint scientific and other projects by students, professors and experts of the company.

\section{DISCUSSION}

including education [6]. Currently, more and more emphasis is moving toward socio-economic partnerships, all the efforts of the state and the vector of its goals are shifting towards the implementation of clearly defined strategic goals for the economic breakthrough in the Russian Federation, which should be provided with appropriate workforce [7].

The solution of these problems is possible by creation and development of universities of the future, the so-called thirdgeneration universities [8], where close cooperation between corporations-employers, graduates and universities themselves is realized [9].

\section{RESULTS}

The master's program "Economics of Oil and Gas Trading" is currently undergoing the initial testing phase. Most likely, the implementation of the training of oil and gas traders and their further functioning at workplaces in the company will allow empirically identifying "weaknesses", respectively, making adjustments to the curriculum and disciplines.

At present, master's program administration and partners from Gazprom Group face diverse tasks, while the immediate prospects are

a) Organizational tasks:

- finding the most effective forms of organizing internships at Gazprom Group;

- organization of internships for students in structural divisions of Gazprom Export LLC and the branch of Gazprom Germany Group in St. Petersburg and in foreign branches;

- organization of the supervision system from the company for the students;

- project scientific and other activities of students and experts from the Gazprom Group;

- business simulations of trading activity on the basis of the branch of the Gazprom Germany Group in St. Petersburg;

b) Tasks in the field of design and research:

- the formation of a bank of cases, project tasks for mastering research and analytical tools, updated in accordance with oil and gas industry issues.

- the most important long-term task, in our opinion, is development partnership between the university and PJSC Gazprom, in the framework of which it will be implemented:

- conducting guest lectures and master classes for students by leading employees of the company;

- internships by professors of SPbSUE at the company's facilities;

\section{A. Cooperation Between Employeers And Universities While Implemention Master Programs}

As a part of the functioning of the National project "Education" is the task of "modernizing vocational education, through the introduction of adaptive, practice-oriented and flexible educational programs" [7]. In the Russian Federation, there are not many successful examples of such programs [10], and mostly they are implemented in skills development system as:

- education of specialists in business schools at universities or licensed institutions [11],

- education in corporate universities of large corporations [12].

At the same time, in the Federal project "Young Professionals" for the years 2019-2024 of the National Project "Education" is stated that by 2024, each educational institution of higher education providing personnel training for basic sectors of the economy and social sphere "together with partners in the real sector of the economy develops adaptive, practice-oriented and flexible educational programs of higher education, which ensure that students receive professional competencies that meet current requirements of the labor market, also in the field of digital economy, entrepreneurship, team and project work, health conservation in relation to their future areas of professional activity "[13].

The practice of making by universities such educational programs by the "order" of the employer for the Russian education system is a new phenomenon. A successful example is the interaction of St. Petersburg State University of Economics (SPbSUE) and PJSC Gazprom in the framework of master's programs designed and implemented by the specialized department of PJSC Gazprom specially created for this task [14].

The advantages of master's programs implemented in partnership with the employer include the following:

1. Expansion of the resource potential by attracting the employer to joint activities. So, in the framework of the program "Economics of Oil and Gas Trading", one of Gazprom Group's subsidiaries organizes business simulations of trading activity.

2. Adaptability to the changing requirements of the labor market, reflecting changes in market conditions, which is a fundamental requirement for the training of future qualified specialists [15].

3. Focus on their core competencies. Much attention is paid in the teaching of disciplines to complex information processing and interpretation, which as higher cognitive skill should be strengthened for workforce by 2030 [16].

4. Effective mechanism for the exchange of information between the university and the employer, replication of best 
TABLE I. SKILLS NEEDED ON WORKPLACE OF OIL AND GAS TRADER cases.

Despite the fact that Gazprom Group has a corporate university, while pursuing the strategy of advanced training of specialists for the development of the corporation, the company relies on core universities, which include St. Petersburg State University of Economics. Two master's programs are implemented by the special department of PJSC Gazprom to train specialists already working in the global energy company:

- since 2015, the master's program "Economic Strategy of a Global Energy Company" (direction "Economics");

- since 2016, the master's program "Strategic Management in a Global Energy Company" (direction "Management").

\section{B. Skills And Competenses Needed For Oil And Gas Traders}

In 2019, at the initiative of PJSC Gazprom, a master's program in Economics of Oil and Gas Trading (direction "Economics") was opened at SPbSUE for those who are going to start working in this field [17]. The need for such specialists arose due to the importance of developing not only oil, but also gas trading in Russia, therefore, in 2017, the professional standard "Oil and Gas Market Trader" appeared, which aims at professional activity to ensure maximum profit from trade in hydrocarbon raw materials and its products processing and minimizing risks [18].

The main labor functions according to the professional standard for the oil and gas market trader are:

- monitoring and analysis of the situation in international commodity-industrial (energy) markets;

- strategic and operational planning of trade transactions and operations;

- conclusion of trade transactions with participants in the oil and gas market;

- administrative, commercial, financial and logistic support of transactions;

- management of trade in hydrocarbon resources.

Based on these labor functions, at the workplace, the graduate of master program "Economics of Oil and Gas Trading" needs to possess the following skills (see Table I).

\begin{tabular}{|c|c|}
\hline Skills & Category \\
\hline $\begin{array}{l}\text { - Quantitative and statistical skills } \\
\text { - Critical thinking and decision } \\
\text { making, } \\
\text { - Complex information processing } \\
\text { and interpretation }\end{array}$ & Higher cognitive skills \\
\hline $\begin{array}{l}\text { - Advanced communication and } \\
\text { negotiation skills } \\
\text { - Leadership and managing others } \\
\text { Entrepreneurship and initiative- } \\
\text { taking }\end{array}$ & $\begin{array}{l}\text { Social and emotional } \\
\text { skills }\end{array}$ \\
\hline $\begin{array}{l}\text { - Advanced data analysis and } \\
\text { mathematical skills, }\end{array}$ & Technological skills \\
\hline \multicolumn{2}{|c|}{$\begin{array}{l}\text { McKinsey Global Institute (May 2018) Skill Shift: } \\
\text { Automation and the Future of the Workforce }\end{array}$} \\
\hline
\end{tabular}

According to a McKinsey report, by 2030, it is precisely these skills that will increase in importance, which makes it possible to judge the prospects and relevance of the trader's profession for the coming decades.

For the formation and development of these skills, special training is required due to the development of new academic disciplines that the university has formed in agreement with the company. The opening of the program was preceded by a lot of preparatory work to develop the unique curriculum. There are no similar programs not only in Russia, but also in the world. The Geneva School of Economics and Management has a Master of Science in Commodity Trading program [19], but it trains broader trading specialists, which shows a comparison of disciplines (Table II). Traineeship is provided in both programs.

Graduates of Geneva School of Economics and Management are able to work in all sectors in Switzerland and abroad in banking, financial institutions, fiduciaries, consulting firms, insurance agencies, local and international manufacturing, international trade companies (e.g., commodities trading, product distribution), international or global organizations. Russian graduates are aimed at work primarily in the field of oil and gas industry. 
for training by Gazprom with a full refund of training costs, twelve received grants differentiated by the amount from the university. Two students are studying at their own expense.

\begin{tabular}{|c|c|c|}
\hline $\begin{array}{c}\text { Comparison } \\
\text { category }\end{array}$ & $\begin{array}{l}\text { Master of Oil and Gas } \\
\text { Trading in } \\
\text { St. Petersburg State } \\
\text { University of } \\
\text { Economics }\end{array}$ & $\begin{array}{c}\text { Master of Science in } \\
\text { Commodity Trading } \\
\text { In Geneva School of } \\
\text { Economics and } \\
\text { Management }\end{array}$ \\
\hline $\begin{array}{l}\text { Related } \\
\text { disciplines }\end{array}$ & $\begin{array}{l}\text { Energy Sector Analysis } \\
\text { Econometrics } \\
\text { (Advanced) } \\
\text { Pricing in global energy } \\
\text { markets } \\
\text { Energy Risk } \\
\text { Management and } \\
\text { Derivatives } \\
\text { Organization of foreign } \\
\text { economic activity in the } \\
\text { oil and gas corporation } \\
\text { International oil and gas } \\
\text { contracts } \\
\text { Oil and gas market } \\
\text { conditions } \\
\text { International Marketing } \\
\text { in Oil and Gas } \\
\text { Corporations } \\
\text { Trade in hydrocarbons } \\
\text { on exchange and over- } \\
\text { the-counter markets }\end{array}$ & $\begin{array}{l}\text { Commodity Price } \\
\text { Mechanism } \\
\text { Hedging Tools \& } \\
\text { Technics } \\
\text { Commodity Price } \\
\text { Risk } \\
\text { International } \\
\text { Economics and Trade } \\
\text { Legal Aspects and } \\
\text { Regulations } \\
\text { Energy Oil and Gas } \\
\text { Shipping market } \\
\text { Trade Finance for } \\
\text { Banking Instruments }\end{array}$ \\
\hline $\begin{array}{l}\text { Matching } \\
\text { disciplines }\end{array}$ & $\begin{array}{l}\text { International Oil and Gas } \\
\text { Logistics / Oil and } \\
\text { Energy Transport } \\
\text { Information Technology } \\
\text { in the Energy Sector }\end{array}$ & $\begin{array}{l}\text { Shipping, Transport \& } \\
\text { Logistics } \\
\\
\text { Information } \\
\text { Technologies and } \\
\text { Innovations }\end{array}$ \\
\hline $\begin{array}{l}\text { Different } \\
\text { disciplines }\end{array}$ & $\begin{array}{l}\text { Modern strategic } \\
\text { management } \\
\text { Energy Research } \\
\text { Methodology } \\
\text { Microeconomics } \\
\text { (Advanced) } \\
\text { Macroeconomics } \\
\text { (Advanced) } \\
\text { Project management in } \\
\text { industries } \\
\text { The role of the global } \\
\text { energy company in the } \\
\text { development of the } \\
\text { international oil and gas } \\
\text { business }\end{array}$ & $\begin{array}{l}\text { Finance and } \\
\text { Investment } \\
\text { Natural Resource } \\
\text { Economy and Agri } \\
\text { Commodities } \\
\text { Metals, Ores \& } \\
\text { Minerals } \\
\text { Energy Renewables } \\
\text { Types of Financing } \\
\text { for Commodity } \\
\text { Companies } \\
\text { Financial Statements } \\
\text { Analysis } \\
\text { Marine Insurance } \\
\text { Sustainable } \\
\text { Finance/Business } \\
\text { Ethics }\end{array}$ \\
\hline
\end{tabular}

The selection of applicants for master program "Economics of Oil and Gas Trading" took place with the involvement of specialists from Gazprom Group, who took part in applicants' interview in English language. The results of the exams and the portfolio competition allowed university to rate the applicants: the best three ones were awarded grants

\section{Tasks of Master's Degree Program in Oil And Gas Trading}

We could summarize the tasks for the master program "Economics of Oil and Gas Trading"

a) In educational activities

- in-depth study and the formation of a systematic view of the development processes of world energy markets;

- formation of student's understanding of trading, including exchange and OTC trading procedures in the hydrocarbon market, risk management, financing of trading operations, hedging of commodity transactions, operational procedures, legal support of transactions, logistics, freight market and conclusion of international contracts;

- formation of professional competencies in the field of oil and gas trading, exchange trading and logistics,

- expanding knowledge of modern forms, methods and tools for the implementation and financing of trade operations, taking into account all aspects of the functioning of modern world energy markets,

- internships.

b) In scientific activity:

- development of research skills;

- formation of the ability to analyze and evaluate challenges, trends, processes, threats in world energy markets;

- writing while studying two scientific articles and publishing both in the journals of the list of the Higher Attestation Commission of the Russian Federation;

- fulfilling research practice requirements.

c) In practical activity:

- acquire skills of project activities;

- internships and practical training in the field of oil and gas trading.

Thus, the implementation of these tasks will allow us to state that the presented master's program fits into the main trends in the development of the Russian magistracy in modern conditions [20], namely:

a) The trend for science - focus on the active research development among students and their introduction into the educational process.

Within the framework of the master program "Economics of Oil and Gas Trading" it could be done 
agenda and expert community of which goes far beyond the framework of a university, region and country;

- annual competition of research works of undergraduates "Oil and Gas Complex: Economics, Politics, Ecology".

\section{REFERENCES}

- at the Youth Day of the annual international conference "Energy of the XXI Century", organized by SPbSUE in partnership and on the initiative of PJSC Gazprom;

- at the industry Student Olympiad of Gazprom in the direction of "Economics".

b) The trend for practice - focus on the development and deepening of professional skills that make it possible to quickly find a job.

This is facilitated by the organization of internships for the best students in the specialized structural divisions of Gazprom Group.

\section{CONCLUSION}

Thus, the article is concentrated on

- the main challenges faced by master's programs in Russia related to the need to educate competitive specialists in the labor market;

- the importance of professional standards for the training of undergraduates, and how they affect the curriculum and comparison with similar foreign master programs;

- the role of the employer for the development of the master's program;

- the main tasks of the development of the master's program in the field of oil and gas trading - scientific, educational and practical.

Thus, Professional standard (7,8 qualification level): "Oil and Gas Market Trader" allows to synchronize the requirements of employer and educational program, and partnership of university and employer as the largest energy company provides prospects for the development of the master's program "Economics of Oil and Gas Trading" and focus, primarily on:

- implementation of the curriculum, which embraces disciplines and modules related to current industry issues;

- project activities initiated by the heads of master's programs with the support of students and program consultants from Gazprom Group;

- providing traineeships for the best students in structural divisions of Gazprom Export LLC and the branch of Gazprom Germany Group in St. Petersburg;

- research and analytical tools, updated in accordance with oil and gas industry issues;

- annual international master's conference, where a section dedicated to energy issues is separately highlighted, the
[1] The Federal law of the Russian Federation "About education in Russian Federation" from 12/29/2012 No. 273-FZ (an edition from 7/29/2017). URL: http://www/consultant/ru/document/cons_doc_LAW_14174/ (date of the address 20.11.2019).

[2] V.V. Galkin, Modernization of Russian education: challenges of the new decade, 2016.

[3] "5 challenges to the education system", Education. Issue, vol. 5(4), 2018, URL: https://plus.rbc.ru/issue/5acc4a987a8aa94d6092811d (date of the address 20.11.2019).

[4] International education strategy: global potential, global growth, 2019, p. 48 .

[5] I.A, Maksimtsev, A.N. Petrov, L.V. Horeva, Transformation of lifelong education: the theory and practice of development master's degree programs in the conditions of economy of knowledge. Monograph for the decade of Institute of Master's programs, vol. 1, 2017, p.87.

[6] E.V. Balatsky, "New Trends in the Development of the University Sector", Mir Rossii, vol. 24(4), pp.72-98.

[7] National project "Education" URL: https://strategy24.ru/rf/education/projects/natsional-nyy-proyektobrazovaniye (date of the address 20.11.2019).

[8] J.G. Wissema, Towards the third generation university : managing the university in transition, 2009.

[9] A.E. Suleimankadieva, "Networking between Universities and Industrial Enterprises: Improving the Master's Program", Planning and Providing Training for the Industrial and Economic Complex of the Region, vol. $1<2018$, pp. 257-258.

[10] B.A. Gladkih, "Could Bologna Process stimulate the improvement of quality and efficiency of education in the Russian higher education

[11] "Business education in the fight for recognition", Education, vol. 5(4), 2018, URL: https://plus.rbc.ru/news/5acbe10c7a8aa94d61f53912 (date of the address 20.11.2019).

[12] Corporate universities http://www.ceo.ru/news/business/school/korporativnye-universiet (date of the address 20.11.2019)

[13] Passport of the national project "Education" URL: http://static.government.ru/media/files/UuG1ErcOWtjfOFCsqdLsLxC8o PFDkmBB.pdf (date of the address 20.11.2019)

[14] I. Blechcin, L. Mierin, A. Petrov, N. Slavetskaya, "Partnership of educational institutions and companies: experience of interaction between SPBSUE and PJSC Gazprom", XIII St. Petersburg Congress "Professional Education, Science and Innovation in the XXI Century", November 20-22, 2019, Collection of works, 2019, pp. 16-19.

[15] R. ODonnellan, Trends 2019: The Future of Work and the Shape of Future Skills, URL: https://www.intuition.com/trends-2019-the-futureof-work-and-the-shape-of-future-skills/ (date of the address 20.11.2019).

[16] J. Bughin, E. Hazan, "Skill Shift: Automation and the Future of the Workforce", McKinsey Global Institute, 2018, URL: https://www.mckinsey.com/ /media/mckinsey/featured\%20insights/futu re\%20of\%20organizations/skill\%20shift\%20automation\%20and\%20the $\% 20$ future $\% 20$ of $\% 20$ the $\% 20$ workforce/mgi-skill-shift-automation-andfuture-of-the-workforce-may-2018.ashx (date of the address 20.11.2019).

[17] Energy New frames of the world exchange. Special Report by Vera Krasova // URL https://www.vesti.ru/videos/show/vid/807178/cid/1219/\# (date of the address 01.11.2019). institution?", Education economy, vol. 6(43), 2007, pp. 4-15. 
[20] T.G. Tumarova, "Trends in the development of master's training in modern conditions: challenges for universities", Lifelong education: lifelong education for sustainable development: Materials of the XVII international conference September 26-28, 2019, pp. 620-623.

approval of the professional standard" Trader of the oil and gas market

"(Registered in the Ministry of Justice of Russia on 09.19.2017 N 48240)

URL:

http://www.consultant.ru/document/cons_doc_LAW_278544/ (date of the address 20.11.2019).

[21] V.V. Galkin, Modernization of Russian education: challenges of the new decade, 2016, p.104.

[19] Master of Science in Commodity Trading// URL: https://www.unige.ch/gsem/en/programs/masters/commodity-trading (date of the address 20.11.2019). 